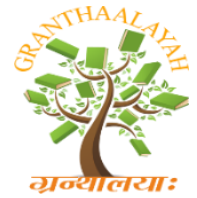

\author{
INTERNATIONAL JOURNAL OF R
GRANTHAALAYAH \\ A knowledge Repository
}

Science

\title{
EVALUATION OF THE BRAIN PLACENTA INDEX AND THE AMNIOTIC LIQUID IN HIGH RISK PREGNANCY AS A PREDICTOR OF LOW APGAR
}

\author{
Dr. Jorge Elias Daher Nader ${ }^{1}$, Obst. Aldo Guzman Soria ${ }^{2}$, Maikel Leyva Vázquez Phd ${ }^{3}$, \\ Dr. Xavier Chan Gomez ${ }^{4}$, Dr. Marlene Isabel Hernandez Navarro ${ }^{5}$ \\ 1,2,3,4,5 University of Guayaquil, Faculty of Medical Sciences, Guayaquil, Ecuador 2019
}

\begin{abstract}
Fetal distress is an alteration of the fetus maternal exchange with disorder in the metabolism due to complications of high-risk pregnancies that affect the well-being of the fetus, Evaluation by Doppler echography and amniotic fluid index can help us to diagnose fetal distress; the Objective of the research was to analyze the Brain placenta index and amniotic fluid index in high-risk pregnancies as a predictor of low Apgar; We investigated pregnant women who attended the hospital Alfredo G Paulson performing Doppler ultrasounds, the result when evaluating the pathologies of high Risk comparing ALI with Apgar was (p.208) and BPI with Apgar was (p.064) which indicates that there are differences so we came to the conclusion that they do not predict if the fetus at the time of birth would present Apgar bass.
\end{abstract}

Keywords: Middle Cerebral Artery; Umbilical Artery; Amniotic Fluid; Fetal Distress.

Cite This Article: Dr. Jorge Elias Daher Nader, Obst. Aldo Guzman Soria, Maikel Leyva Vázquez Phd, Dr. Xavier Chan Gomez, and Dr. Marlene Isabel Hernandez Navarro. (2020). "EVALUATION OF THE BRAIN PLACENTA INDEX AND THE AMNIOTIC LIQUID IN HIGH RISK PREGNANCY AS A PREDICTOR OF LOW APGAR.” International Journal of Research - Granthaalayah, 8(1), 12-17. 10.29121/granthaalayah.v8.i1.2020.237.

\section{Introduction}

The ultrasound evaluation of the middle cerebral artery resistance index and umbilical together with the amniotic fluid help us to determine the fetal well-being, nowadays they are of great importance they work as a diagnostic method and are realized with the purpose of identifying the fetuses that are at risk of having an adverse outcome due to a high risk pregnancy (1.11).

Fetal distress is an alteration of fetal-mother exchange with disorder in the metabolism that leads to irreparable tissue alteration until the death of the fetus. It is characterized by hypoxia and acidosis where its consequences can cause multi-organ damage, encephalic and cerebral palsy (1). 
Due to a stage of fetal hypoxemia as a consequence of the reduction in oxygen, hypoxia in the tissues is produced, in a hypoxia stage the energetic needs of the cell are given by carbohydrates, lipid proteins and other elements that are degraded via anaerobia reducing the oxygen consumption and accumulating hydrogenations increasing the acidosis (1). The early decline in glycogen and the failure in the metabolism of the potassium will cause complications at the myocardium level that if the hypoxic stage is exacerbated or it is maintained for a long time will enter shock producing irreparable damages or even the death death of the fetus (3). The reactions that the fetus produces due to an established hypoxic state has a direct relation in the increase of the sympathetic tone, which can be evidenced in the increase of the cardiac frequency, this would be the first valuable sign to suspect of fetal distress, when the oxygen levels fall below the normal levels the vagal tone is stimulated and the fetal heart rate is reduced as a means of saving energy, decreasing the disorders caused by fetal distress (2).

The objective of our study was to analyze the Brain-Placenta Index (BPI) and the Amniotic Liquid Index (ALI) in high-risk pregnancy as a predictor of low Apgar.

\section{Material and Method}

We executed the research on pregnant women, who attended and met the inclusive criteria at the Hospital Alfredo G. Paulson, where the Doppler ultrasound and the evaluation of the amniotic liquid was performed from September of 2016 to April of 2017.

The ultrasound exam was realized measuring the resistance index of the middle cerebral artery and umbilical. Also, the measurement of amniotic liquid was made measuring the quadrants following the universal criteria and table of values to reach the correct diagnose.

The Doppler and amniotic liquid measurements were carried out using a General Electric Logig F8 ultrasound machine. The evaluated results were:

index of resistance of the middle cerebral artery. b) index of resistance of the umbilical artery. c) high risk for obstetrics pathologies. d) presence of perinatal asphyxia. e) weight of the fetus. g) gestational age at birth through the Usher method.

The inclusive criteria were: 1) All maternal ages, 2) Pregnancies greater than 26 weeks, 3) Hypertension induced by the pregnancy, 4) Gestational Diabetes, 5) Oligohydramnios, 6) Early break of membranes, 7) Post term pregnancy, 8) Anemia, 9) Patients in prepartum period, 10) Fetal Dystocia, 11 placenta previa ,12) Chronic Illnesses .

The exclusion criteria were: 1) Eclampsia, 2) Placenta Previa, 3) Umbilical Cord Prolapse, 4) Pregnancies less than 26 weeks, 5) Expulsive period, 6) Hypovolemic shock.

The data were exposed to a descriptive statistical analysis in which tests of central tendency and comparative analysis with Anova were using R. software.

\section{Results}

The minimum age was 14 years and the maximum age was 49 years with a mean of 27.2 years and the median of 27.5 years. 
The parity encompassed women from their first pregnancy up to 6 gestations, as obstetric history the median was 1 gestation and the mean was 1,28 gestations.

The assessment of the index brain placenta was the minimum of 0,37 the maximum of 1,96 the mean of 1, 27 and the median of 1,29.

The assessment of the amniotic liquid was ALI: absence of the minimum and the maximum of ALI: 37 the median was of ALI: 11, 44 and the mean of ALI: 11.22

In the study the minimum weeks of gestation were 29 and maximum of 40 weeks.

The result of assessing high-risk pathologies comparing the ALI with the Apgar was (p-0.208) and the BPI with the Apgar was (p-0.064).

Table I shows the mean of the pathologies that were studied.

Table II shows the pathologies with the mean of the amniotic liquid, Apgar and the Anova.

Table III shows the pathologies with the mean of the Index Brain-Placenta, Apgar and the Anova.

Table I: Studied Variables

\begin{tabular}{|l|c|c|c|c|c|c|c|c|c|}
\hline Pathologies & Cases & Age & Gestations & Bpi & Ali & P.gest & Weight & Size (cm) & Apgar \\
\hline Rpm & 20 & 25 & 1 & 1.31 & 9.37 & 38 & 3.181 & 48 & 7,55 \\
& & & & & & & & & \\
\hline Preeclampsia & 6 & 28 & 1 & 1,4 & 11 & 37 & 2.729 & 46 & 7,2 \\
\hline Fetal Dystocias & 16 & 30 & 2 & 1,3 & 13 & 38 & 3,048 & 48 & 7,5 \\
\hline Alteration: Amniotic Liquid & 9 & 25 & 1 & 1,1 & 6 & 34 & 1,929 & 41 & 6,33 \\
& & & & & & & & & \\
\hline Digestive Pathologies & 3 & 25 & 2 & 1,3 & 10 & 37 & 2,381 & 45 & 7,66 \\
\hline Placenta previa & 6 & 30 & 2 & 1,1 & 10 & 36 & 2,332 & 45 & 7 \\
\hline Endocrine Pathologies & 7 & 29 & 2 & 1,3 & 20 & 37 & 3,328 & 49 & 6 \\
\hline Renal Pathology & 3 & 25 & 1 & 1,4 & 13 & 36 & 2,633 & 45 & 6 \\
\hline
\end{tabular}

Table 2: Amniotic liquid and appgar.

\begin{tabular}{|l|c|c|c|c|}
\hline Pathologies & Cases & Ali & Apgar & Q \\
\hline Rpm & 20 & 11 & 7,2 & 0,364 \\
\hline Preeclampsia & 6 & 9,4 & 7,55 & 0,05 \\
\hline Fetal Dystocia & 16 & 13 & 7,5 & 0,393 \\
\hline Alteration: Amniotic Liquid & 9 & 6 & 6,33 & 0,051 \\
\hline Digestive Pathologies & 3 & 10 & 7,66 & 0,343 \\
\hline Placenta previa & 6 & 10 & 7 & 0,445 \\
\hline Endocrine Pathologies & 7 & 20 & 6 & 0,609 \\
\hline Renal Pathology & 3 & 13 & 6 & 0,0006 \\
\hline
\end{tabular}

The comparison of the amniotic liquid with the neonatal result (Apgar) was made through the analysis of the variance (Anova) with R Software. 
Table 3: Brain-placenta index and apgar.

\begin{tabular}{|l|c|c|c|c|}
\hline Pathologies & Cases & Bpi & Apgar & Q \\
\hline Rpm & 20 & 1,4 & 7,2 & 0,112 \\
\hline Preeclampsia & 6 & 1,3 & 7,55 & 0,1 \\
\hline Fetal Dystocia & 16 & 1,3 & 7,5 & 0,671 \\
\hline Alteration: Amniotic Liquid & 9 & 1,1 & 6,33 & 0,99 \\
\hline Digestive Pathologies & 3 & 1,3 & 7,66 & 0,152 \\
\hline Placenta previa & 6 & 1,1 & 7 & 0,574 \\
\hline Endocrine Pathologies & 7 & 1,3 & 6 & 0,07 \\
\hline Renal Pathology & 3 & 1,4 & 6 & 0,358 \\
\hline
\end{tabular}

The comparison of the amniotic liquid with the neonatal result (Apgar) was made through the analysis of the variance (Anova) with R Software.

\section{Discussion}

Our study gave as a result that there are differences between ALI valued before delivery or cesarean section and Apgar so the assessment won't indicate if the fetus will have a low Apgar at birth, the evaluation of the brain-placenta index revealed that there are many differences with the Apgar at birth as a result these measurements won't indicate either entirely if the fetus will have a low Apgar at birth. $(5,13)$.

The measurement of the artery flow helped detect the adaptive process of the redistribution of blood to important organs primary sign of fetal distress so their indication assisted to have a better knowledge of how the fetus is inside the (4). The amniotic liquid is the medium for the development of the fetus, it provides protection and its reduction is associated with cardiac fetal frequency, besides that it is important to know the hours of rupture since it is associated with chorioamnionitis with rein the fetal well-being, and also to know if there are renal and fetal intestinal pathologies because they help to normal maintain values (6).

The umbilical arteries assess the vascular function fetus-placenta. During pregnancy the resistance of the umbilical artery is diminishing; the middle cerebral artery, a branch of the internal carotid artery, is a blood vessel of high resistance that is reduced through pregnancy but it always maintains high resistance in with the umbilical artery (4).

When fetal distress is established the values of the resistance of the middle cerebral artery decreases while the values of the resistance of the umbilical artery increases, this is known as Brain-Sparing Effect, with the objective of providing oxygen to organs such as heart, brain and adrenal glands (7). High risk pregnancies are associated with hemodynamic alterations, pathologies such as preeclampsia where there were an incorrect remodeling of the spiral arteries by the trophoblast would indicate that the blood flow will be reduced so the consequence will be seen in a reduction of the amniotic liquid (8). In diabetes we can find an increase in the amniotic liquid due to Osmotic Diuresis (9). In maternal digestive pathologies the level of compromise of the stomach mucosa will result in a reduction of the intrinsic factor that will aid to transport vitamin b12, its reduction will lead to maternal anemia $(10,12)$. At the time of evaluation by the Doppler ultrasound we could have anomalous results due to these pathologies, the fetal dystocia can put at 
risk the fetus because of the changes could compromise its physiological functions, thus the Doppler evaluation through the movement brain-placenta and the index of the amniotic liquid will help to determine whether the fetus is under fetal distress which will put in alert to take the necessary to measure the life of the fetus.

\section{Conclusion}

The assessment of the amniotic liquid and the Doppler Echography to know the neonatal result in our study demonstrated that there exist differences so evaluating other clinical parameters will help to fundament if the fetus is suffering from fetal distress and can evaluate with effectiveness if at birth the fetus will show a low Apgar.

\section{Confidentiality}

The personal data of the patient has been protected as indicated by medical ethics

\section{Conflict of Interests}

The authors declare that does not exist an interest conflict.

\section{References}

[1] Náples Mendez D, Pilot Padrón M. Physiological foundations on suffocation in peripartum. MEDISAN [Internet]. 2014 Mar [cited 2017 Jun 11]; 18(3): 393-407. Available in: http://scielo.sld.cu/scielo.php?script=sci_arttext\&pid=S1029-30192014000300014\&lng=es.

[2] Espinoza R J. Fetal suffering. Rev. Chil. pediatrics. [Internet]. 1973 Dec [cited 2017 Jun 11]; 44 (6): 523-529. Available in: http://www.scielo.cl/scielo.php?script=sci_arttext\&pid=S037041061973000600002\&lng=es. http://dx.doi.org/10.4067/S0370-41061973000600002

[3] Naples Méndez D. Current controversies to define alterations of fetal well-being. MEDISAN [Internet]. 2013 Mar [cited 2017 Jun 11]; 17(3): 521-534. Available in: http://scielo.sld.cu/scielo.php?script=sci_arttext\&pid=S1029-30192013000300014\&lng=es

[4] Ventura Laveríano Wa, Mazarlo Redondo C. Sclinical ignified pathological doppler in the median cerebral artery in third trimester fetuses. Rev. Chil. obstet. gynaecologist. [Internet]. 2010 [cited 2017 Jun 10]; 75(6): 405-410. Available in:

http://www.scielo.cl/scielo.php?script=sci_arttext\&pid=S0717-

75262010000600010\&lng=es. http://dx.doi.org/10.4067/S0717-75262010000600010

[5] Except FB, Flowers A J, Alarcón R J, N acharH R, Paredes V. Low apgar test risk factors in newborns. Rev. Chil. pediatrics. [Internet]. 2007 Jun [cited 2017 Jun 10]; 78(3): 253-260. Available in:

http://www.scielo.cl/scielo.php?script=sci_arttext\&pid=S037041062007000300003\&lng=es. htt p://dx.doi.org/10.4067/S0370-41062007000300003

[6] Amador de Varona Ca I, Rodríguez Fernández J M, Mari Pichardo A, Valdés Dacal Sigfrido. Oligohydramnios: fetal health meter. AMC [Internet]. 2013 Dec [cited 2017 Jun 11] ; 17( 6 ): 121128.Availablein:http://scielo.sld.cu/scielo.php?script=sci_arttext\&pid=S10250255201300060000 $7 \& \operatorname{lng}=\mathrm{es}$

[7] Martinovic Titiro C, Carvajal C J A. Placental brain index in adverse perinatal result prediction and fetal heart rate alterations in uncomplicated pregnancies of 40 weeks and more. Rev. Chil. obstet. gynaecologist. [Internet]. 2015 Dec [cited 2017 Jun 11]; 80(6): 520-522. Available in: 
http://www.scielo.cl/scielo.php?script=sci_arttext\&pid=S071775262015000600014\&lng=es. htt p://dx.doi.org/10.4067/S0717-75262015000600014

[8] Parra C Mauro, San Martín O A, Valdés R E, Hasbún H Jorge, Quiroz V L, Schepeler S M et al. Clinicalespectro of preeclampsia: comparative study of its varying degrees of severity. Rev. Chil. obstet. gynaecologist. [Internet]. 2007 [cited 2017 Jan 20]; 72(3): 169-175. Available in: http://www.scielo.cl/scielo.php?script=sci_arttext\&pid=S0717-75262007000300007\&lng=es. http://dx.doi.org/10.4067/S0717-75262007000300007.

[9] Clapés Hernández S. Diabetes mellitus, oxidative stress and pregnancy. Rev Cubana Invest Bioméd [Internet]. 2000 Dec [cited 2017 Jan 20]; 19(3): 191-195. Available in: http://scielo.sld.cu/scielo.php?script=sci_arttext\&pid=S0864-03002000000300008\&lng=es.

[10] Peace R. From, Hernandez-Navarro F.. Management, prevention and control of pernicious anemia. Mr. Nutr. Hosp. [Internet]. 2005 Dec [cited 2017 Jun 12]; 20(6): 433-435. Available in: http://scielo.isciii.es/scielo.php?script=sci_arttext\&pid=S0212-16112005000800011\&lng=es.

[11] Martínez González L R, Torres García W,Pérez Martínez C. Experience with the fetal biophysical profile in our environment. Rev Cuban Obstet Ginecol [Internet]. 1997 Jun [cited 2017 Jan 20]; 23 (1):31-36. Available in: http://scielo.sld.cu/scielo.php?script=sci_arttext\&pid=S0138600X1997000100006\&lng=es.

[12] Becerra César, Gonzales G F., Villena Ar, de la Cruz D, F A. Prevalence of anemia in pregnant women, Pucallpa Regional Hospital, Peru. Rev Panam Public Health [Internet]. 1998 May [cited 2017 Jan 20]; 3(5): 285-292. Available from:

http://www.scielosp.org/scielo.php?script=sci_arttext\&pid=S1020-49891998000500001\&lng=en. http://dx.doi.org/10.1590/S1020-49891998000500001.

[13] Tejerina Morató H. Neonatal asphyxiation. Rev. Bowl. Ped. [Internet]. 2007 Jun [cited 2017 Jun 11]; 46(2): 145-150. Available in:

http://www.scielo.org.bo/scielo.php?script=sci_arttext\&pid=S1024-

06752007000200012\&lng=es.

\footnotetext{
*Corresponding author.

E-mail address: jorge.dahern@ug.edu.ec/aldo.guzmans@ug.edu.ec/maikel.leivav@ug.edu.ec/ xavier.chang@ug.edu.ec/marlene.hernandezn@ug.ecu.ec
} 